\title{
非線形カルマンフィルタを用いた車体スリップ角の推定*
}

\author{
永井 惊也 ${ }^{* 1}$, 孕石 泰丈 ${ }^{* 2}$, 塩澤 裕樹 $^{* 1}$, 毛利 宏 ${ }^{* 2}$

\section{Investigation on Estimation of Vehicle Side Slip Angle by Using Extended Kalman Filter} \\ Junya NAGAI*1, Yasutake HARAMIISHI, \\ Yuuki SHIOZAWA and Hiroshi MOURI

\footnotetext{
${ }^{* 1}$ University of Yamanashi, Graduate School of Medical and Engineering Department of Education
} \\ 4-3-11, Takeda, Kofu-shi, Yamanashi, 400-8511 Japan
}

The extended Kalman filter was employed to estimate vehicle side-slip angle accurately even under the condition of low road friction and the large lateral gradient road. The direct integration method is the base structure of this estimator, and the longitudinal equation of motion was included to augment the system , and to configure the Kalman filter. For compensation of estimation value drifted by the sensor signal offset, a nonlinear map between actual yawrate and the yawrate value using in the calculation was proposed. The performance of the extended Kalman filter and the non-linear map was validated in the simulation.

Key Words : Vehicle Dynamics, Automobile, Handling and Stability, Observer, Sensor

\section{1. 緒言}

電動モータによる制駆動力制御(1) (4)やX-BY-WIRE システムに代表されるように，車両運動性能を向上させる さまざまなシステムが現実のものになりつつある。これらのシステムではその出力を高精度に制御でき，制駆動 力や車輪回転数，ステア角などの状態が正確に把握できるようになった．しかし相変わらず並進速度に関する車 両状態量に関しては直接計測することが難しく, 車体スリップ角についても一般的に推定值が用いられる年 (13) $^{\text {. }}$. 車体スリップ角情報は車両運動制御性能に大きく影響するため，その推定精度を向上させることには大きな意 義がある．例えばタイヤ線形領域では，車体スリップ角の発生量やタイミングと「ドライバの運転しやすさ」と の間の密接な関係が多く報告されている ${ }^{(14)(15)}$. また，車両挙動が不安定になることを防止する横滑り防止装置に は，車体スリップ角の高精度推定は必須の性能であることが広く知られている．本報では，次章に記す従来の車 体スリップ角推定方法の問題点を解決し， より正確な推定值を得るために開発した手法の検討結果を報告する.

\section{2. 従来の推定方法}

従来の車体スリップ角推定方法は下記のように二つの代表的な手法に大別される.

(1) 車両モデルを用いた線形オブザーバによる推定

(2) 式(1)に基づいた積分計算による推定（直接積分法）

線形オブザーバ(1)では車両モデルが正確であれば，精度の高い推定值が得られる. しかし，図 1 に示すように 路面摩擦係数 $\mu$ の変化やタイヤ非線形特性などの影響を受けて，モデル化誤差が大きい場合には十分な精度が得 られない．低 $\mu$ 路や高い加速度を伴う走行中に車体スリップ角を正確に推定することは安全性の観点からも重要 であり, このような状況での推定精度の低下は大きな課題と言える.

直接積分法(2)式(1)に基づいた積分計算で推定値を得る.

\footnotetext{
* 原稿受付 2013 年 3 月 6 日

${ }^{* 1}$ 山梨大学大学院 医学工学総合教育部（广400-8511 山梨県甲府市武田 4丁目 3-11）

*2 正員, 山梨大学 医学工学総合研究部

E-mail:hmohri@yamanashi.ac.jp
} 


$$
\beta=\int_{0}^{t}\left(\frac{G_{y}}{u}-r\right) d t
$$

この方法は車両モデルを持たず，車載センサ信号を直接使用するので，原理的には路面摩擦係数 $\mu$ の変化や夕 イヤの非線形特性の影響を受けずに動作する。しかし，式(1)からわかるように，積分計算によってセンサノイズ やオフセットの影響が推定值に蓄積される. その結果，図 1 に示すような推定值のドリフトが問題となる.

以下，モデル化誤差の影響を受けずに，さまざまな状況での推定誤差を抑制しつつセンサノイズ，オフセット に対してもドリフトの少ない推定器の検討結果について述べる.

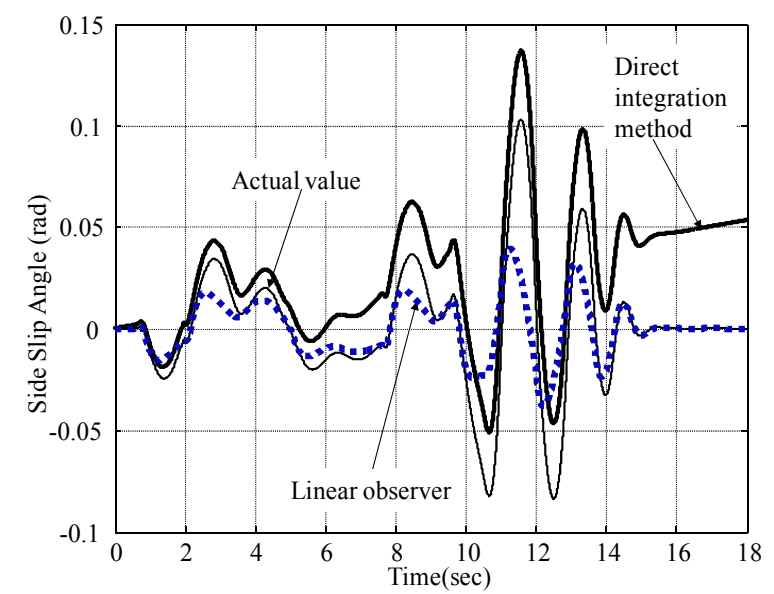

Fig.1 $\beta$ estimation during lane change on the road with $\mu=0.4$

\section{3. 剛体の運動方程式}

本研究では，直接積分法をベースとした車両モデルを持たない簡単な推定器を提案する．簡単に言うとセンサ 信号のオフセットがあっても推定值がドリフトしない直接積分法を提案する. 具体的には横方向の運動方程式だ けではなく，前後方向の運動方程式も追加してオブザーバを構成する.

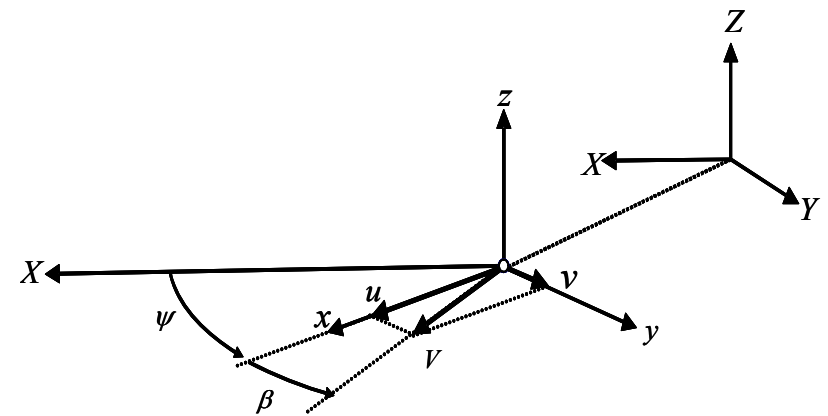

Fig.2 Inertial coordinate system and vehicle coordinate system

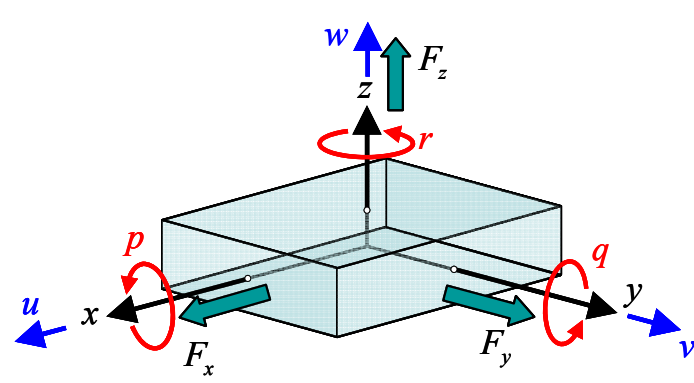

Fig. 3 Vehicle coordinate system

以下, 剛体の運動方程式について簡単に記す(16)(17). 図 2,3 のように絶対空間座標系 $X Y Z$ 上を運動する車両に固 定した座標系を $x y z$ で表現する. 各記号は以下の通り.

<記号の説明 $>$

$u: x$ 方向速度（前方速度）

$p:$ ロールレイト $(x$ 軸周り角速度 $)$

$\beta:$ 車体スリップ角

$F_{x}: x$ 方向外力（前方向外力）

$\alpha_{x}: x$ 方向加速度 $v: y$ 方向速度（左方向速度）

$q$ : ピッチレイト ( $y$ 軸周り角速度 $)$

$V:$ 車速べクトル

$F_{y}: y$ 方向外力 (左方向外力)

$\alpha_{y}: y$ 方向加速度 $w: z$ 方向速度（上方向速度）

$r:$ ヨーレイト $(z$ 軸周り角速度 $)$

$g:$ 重力加速度

$F_{z}: z$ 方向外力 (上方向外力)

$\alpha_{z}: z$ 方向加速度 

$G_{x}: x$ 方向加速度センサ信号
$G_{y}: y$ 方向加速度センサ信号
$G_{z}: z$ 方向加速度センサ信号
$\phi:$ ロール角 $(x$ 軸周り回転角度 $)$
$\theta:$ ピッチ角 $(y$ 軸周り回転角度)
$\psi$ : ヨ一角 $(z$ 軸周り回転角度 $)$

六自由度剛体の慣性系での運動方程式を導出する. 車両重心の速度ベクトルは式(2), 式(3)で表される.

$$
\begin{aligned}
& V=u i+v j+w k \\
& \omega=p i+q j+r k
\end{aligned}
$$

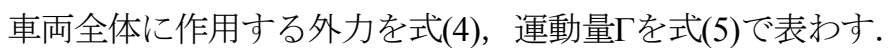

$$
\begin{aligned}
& F=F_{x} i+F_{y} j+F_{z} k \\
& \Gamma=m(u i+v j+w k)
\end{aligned}
$$

式(5)の運動量「を時間で微分すると慣性系で剛体に作用する外力となり，式(6)のように運動方程式が導かれる. 尚，車両固定座標系の各軸方向の単位ベクトルの時間微分には式(7)を用いた.

$$
\begin{aligned}
& m \alpha_{x}=m(\dot{u}-v r+w q)=F_{x} \\
& m \alpha_{y}=m(\dot{v}-w p+u r)=F_{y} \\
& m \alpha_{z}=m(\dot{w}-u q+v p)=F_{z} \\
& \frac{d}{d t}\left(\begin{array}{l}
i \\
j \\
k
\end{array}\right)=\left(\begin{array}{ccc}
0 & r & -q \\
-r & 0 & p \\
q & -p & 0
\end{array}\right)\left(\begin{array}{l}
i \\
j \\
k
\end{array}\right)
\end{aligned}
$$

式(6)は慣性系での運動方程式であり，地上では重力の影響を考慮する.

図 4 に示すようにヨー方向, ピッチ方向, ロール方向の座標変換を行ったときの変換行列は式(8)で与えられる. 尚，図 4 中の座標軸に付加された*，**は回転による変換の途中で作られた座標系の軸を表わす。

$$
\left(\begin{array}{l}
x \\
y \\
z
\end{array}\right)=\left(\begin{array}{ccc}
\cos \theta \cos \psi & \cos \theta \sin \psi & -\sin \theta \\
\sin \phi \sin \theta \cos \psi-\cos \phi \sin \psi & \sin \phi \sin \theta \sin \psi+\cos \phi \cos \psi & \sin \phi \cos \theta \\
\cos \phi \sin \theta \cos \psi+\sin \phi \sin \psi & \cos \phi \sin \theta \sin \psi-\sin \phi \cos \psi & \cos \phi \cos \theta
\end{array}\right)\left(\begin{array}{l}
X \\
Y \\
Z
\end{array}\right)
$$

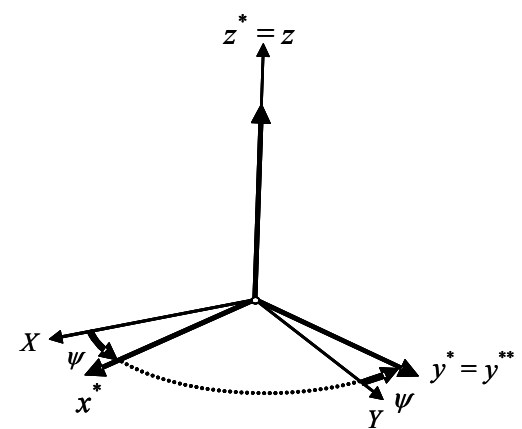

(a)Rotation around z-axis

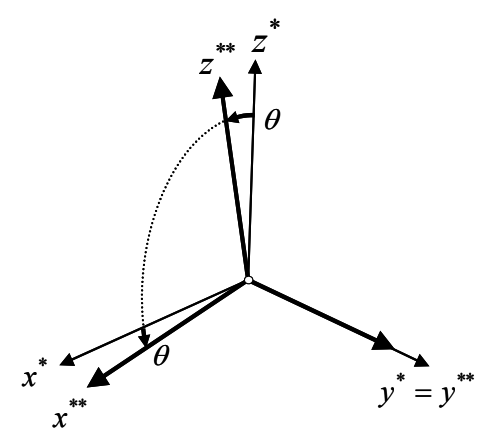

(b)Rotation around y-axis

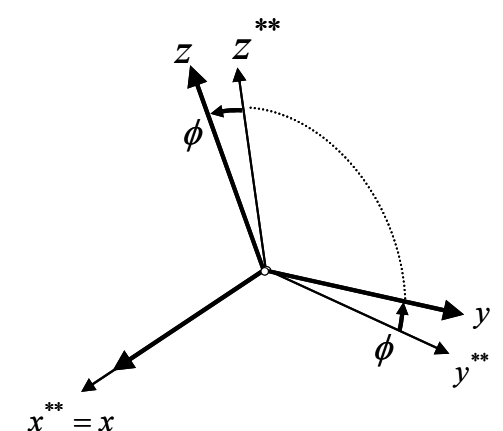

(c)Rotation around $\mathrm{x}$-axis

Fig. 4 Rotation of Coordinate system

車載された加速度センサの信号には慣性加速度に重力加速度成分が加わる．慣性座標系における重力加速度べ クトルを式(8)で車両座標に変換すると式(9)が得られる.

$$
\left(\begin{array}{ccc}
\cos \theta \cos \psi & \cos \theta \sin \psi & -\sin \theta \\
\sin \phi \sin \theta \cos \psi-\cos \phi \sin \psi & \sin \phi \sin \theta \sin \psi+\cos \phi \cos \psi & \sin \phi \cos \theta \\
\cos \phi \sin \theta \cos \psi+\sin \phi \sin \psi & \cos \phi \sin \theta \sin \psi-\sin \phi \cos \psi & \cos \phi \cos \theta
\end{array}\right)\left(\begin{array}{c}
0 \\
0 \\
-g
\end{array}\right)=\left(\begin{array}{c}
g \sin \theta \\
-g \sin \phi \cos \theta \\
-g \cos \phi \cos \theta
\end{array}\right)
$$


以上より，加速度センサから得られる信号は次のように書ける.

$$
\begin{aligned}
& \dot{u}-r v+w q=g \sin \theta+G_{x} \\
& \dot{v}-w p+r u=-g \cos \theta \sin \phi+G_{y} \\
& \dot{w}-u q+v p=-g \cos \theta \cos \phi+G_{z}
\end{aligned}
$$

\section{4. 拡張カルマンフィルタの構成}

式(10)において上下速度, ロールレイト, ピッチレイトをゼロで近似した時の前後方向, 横方向の運動方程式 は以下になる.

$$
\left(\begin{array}{c}
\dot{u} \\
\dot{v}
\end{array}\right)=\left(\begin{array}{cc}
0 & r \\
-r & 0
\end{array}\right)\left(\begin{array}{l}
u \\
v
\end{array}\right)+\left(\begin{array}{ll}
1 & 0 \\
0 & 1
\end{array}\right)\left(\begin{array}{l}
G_{x} \\
G_{y}
\end{array}\right)+\left(\begin{array}{c}
g \sin \theta \\
-g \cos \theta \sin \phi
\end{array}\right)
$$

式(11)において，車両は各加速度センサ信号でその状態が駆動されると共に，重力による外乱が加わった系と みなすことができる. 式(11)はシステム行列にヨーレイトを含む時変非線形系であり，このシステムに対して拡 張カルマンフィルタを下記のように構成した ${ }^{(18) \sim(23)}$.

$$
\begin{aligned}
& \left(\begin{array}{c}
\bar{u}_{t} \\
\bar{v}_{t} \\
\bar{w}_{1, t} \\
\bar{w}_{2, t}
\end{array}\right)=\left(\begin{array}{cccc}
1 & r_{t-1} d t & d t & 0 \\
-r_{t-1} d t & 1 & 0 & d t \\
0 & 0 & 1 & 0 \\
0 & 0 & 0 & 1
\end{array}\right)\left(\begin{array}{c}
u_{t-1} \\
v_{t-1} \\
w_{1, t-1} \\
w_{2, t-1}
\end{array}\right)+\left(\begin{array}{c}
G_{x, t} d t \\
G_{y, t} d t \\
0 \\
0
\end{array}\right) \\
& L_{t} \equiv J\left(x_{t-1}\right) \equiv \frac{\partial \bar{x}_{t}}{\partial x_{t-1}} \equiv\left(\begin{array}{cccc}
1 & r_{t-1} d t & d t & 0 \\
-r_{t-1} d t & 1 & 0 & d t \\
0 & 0 & 1 & 0 \\
0 & 0 & 0 & 1
\end{array}\right) \\
& \bar{\Sigma}_{t}=L_{t} \sum_{t-1} L_{t}^{T}+R_{t} \\
& H_{t} \equiv \frac{\partial h\left(\bar{x}_{t}\right)}{\partial x_{t-1}}=\left(\begin{array}{lll}
\frac{\partial \bar{u}_{t}}{\partial \bar{u}_{t}} & \frac{\partial \bar{u}_{t}}{\partial \bar{v}_{t}} & \frac{\partial \bar{u}_{t}}{\partial \bar{w}_{1, t}}
\end{array} \frac{\partial \bar{u}_{t}}{\partial \bar{w}_{2, t}}\right)=\left(\begin{array}{llll}
1 & 0 & 0 & 0
\end{array}\right) \\
& K_{t}=\bar{\Sigma}_{t} H_{t}^{T}\left(H_{t} \bar{\Sigma}_{t} H_{t}^{T}+Q_{t}\right)^{-1} \\
& \left(\begin{array}{c}
u_{t} \\
v_{t} \\
w_{1, t} \\
w_{2, t}
\end{array}\right)=\left(\begin{array}{c}
\bar{u}_{t} \\
\bar{v}_{t} \\
\bar{w}_{1, t} \\
\bar{w}_{2, t}
\end{array}\right)+K_{t}\left(u_{t_{-} \text {sensor }}-\bar{u}_{t}\right) \\
& \sum_{t}=\left(I-K_{t} H_{t}\right) \bar{\Sigma}_{t}
\end{aligned}
$$

添字 $t$ は時刻を表し, 変数上のバーは状態方程式(12)に基づく予測值であることを示す. また, 式(12)において, 重力加速度外乱の影響はランダムウォークモデルで表わした．各記号は以下の通り．
$G_{t}:$ 予測に関するヤコビアン
$H_{t}:$ 計測に関するヤコビアン
$d t:$ 演算更新時間
$R_{t}:$ プロセスノイズの共分散
$Q_{t}:$ 観測ノイズの共分散
$\Sigma_{t}:$ 状態量の共分散

$K_{t}:$ カルマンゲイン $\left(k_{1}, k_{2}\right.$ は $K_{t}$ の成分 $)$

$u_{t \text { sensor }}$ : 車速センサ信号

上記カルマンフィルタによって前後速度 $u$ と横速度 $v$ を推定し, 車体スリップ角 $\beta$ は式(19)で計算される.

$$
\beta=\tan ^{-1} \frac{v}{u}
$$




\section{5. シミュレーション結果}

車両シミュレーションソフト $\mathrm{CarSim}^{(24)}$ の計算データを, 実験で得られたセンサデータとみなして各推定器に入 カし，推定した結果を示す.

ダブルレーンチェンジと旋回制動実験を想定して計算を行った. 試験コースの形状を図 5,6 に示す.レーンチェ ンジは車速 $120 \mathrm{~km} / \mathrm{h}$ 一定で, 路面 $\mu$ を種々に変えて計算した. 旋回制動では路面 $\mu$ を 0.85 とし車速 $130 \mathrm{~km} / \mathrm{h}$ から 一定ブレーキ圧をかけて減速度約 $0.2 \mathrm{G}$ で制動した.

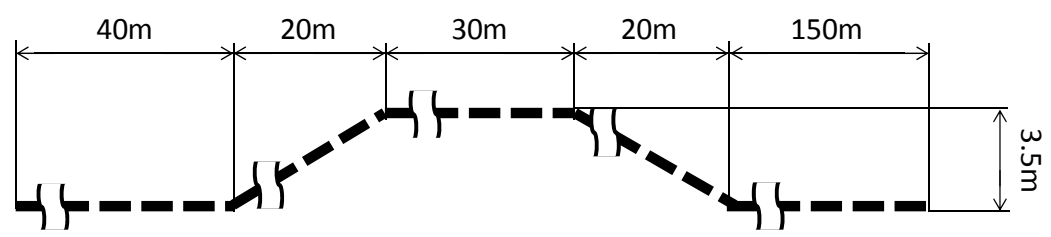

Fig.5 Configuration of Test Course (Double Lane Change)

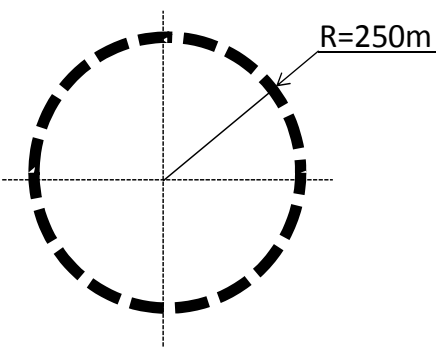

Fig.6 Configuration of Test Course (Braking during Cornering)

図 7, 8 にはダブルレーンチェンジ時の車体スリップ角推定值の時系列波形を示した. 図 7 は路面 $\mu=0.85$, 図 8 は路面 $\mu=0.40$ での結果である. 両者共に横加速度センサに $0.01 \mathrm{G}$ のオフセットを加えている.

図 7 では路面 $\mu$ が高く, 車両のモデル化誤差が少ないため, 線形オブサーバで精度良く推定されることがわか る. 直接積分法ではセンサオフセット影響を受け，推定值にドリフトが発生している．拡張カルマンフィルタを 用いた提案手法では, 線形オブザーバには劣るが実用上十分な推定精度が得られている. 推定值がセンサオフセッ トの影響を受けない理由は 6 章に述べる.

図 8 では路面 $\mu$ が低く，モデル化誤差が生じるため, 線形オブザーバの推定誤差は大きい. 直接積分法はオフ セットの影響で推定值にドリフトが発生するが，その影響を除去できれば線形オブザーバよりも真值に近い推定 の可能性が推察される．提案手法はモデルを持たないために路面 $\mu$ にらず高い精度で推定できている.

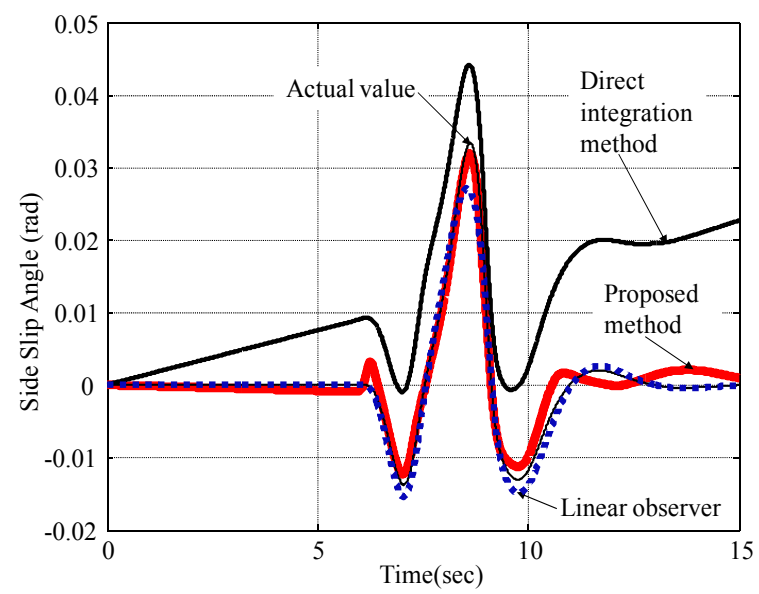

Fig.7 $\beta$ estimation during lane change on the road with $\mu=0.85$

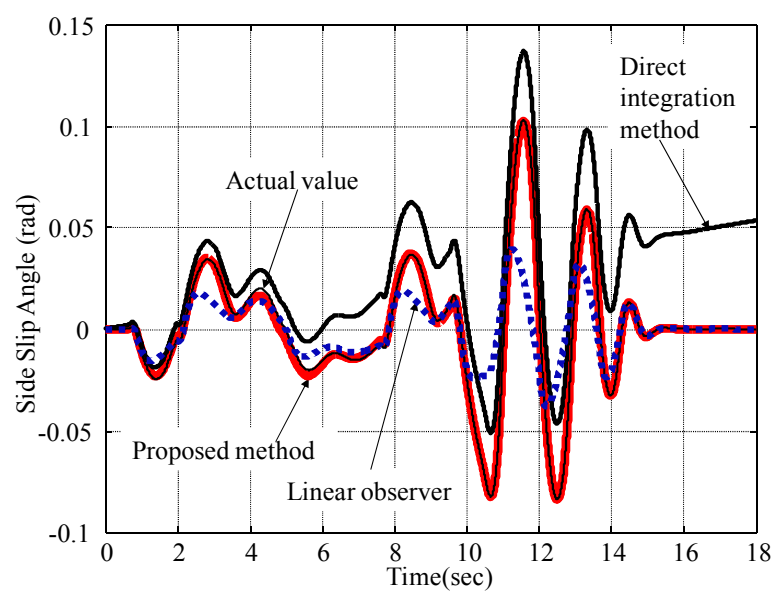

Fig.8 $\quad \beta$ estimation during lane change on the road with $\mu=0.4$ 
図 9 に旋回制動時の結果を示す. 線形オブザーバは車速 $20 \mathrm{~km} / \mathrm{h}$ 毎に複数の推定器を用意し, 車速に応じて各 推定值を線形補間したが推定誤差が大きい. 提案手法では, 従来の方法よりも真值に近い推定值が得られるもの の, 大きな推定誤差を生じる結果となった。 これは加減速によるピッチングで前後方向の重力加速度成分が大き く発生したためである.

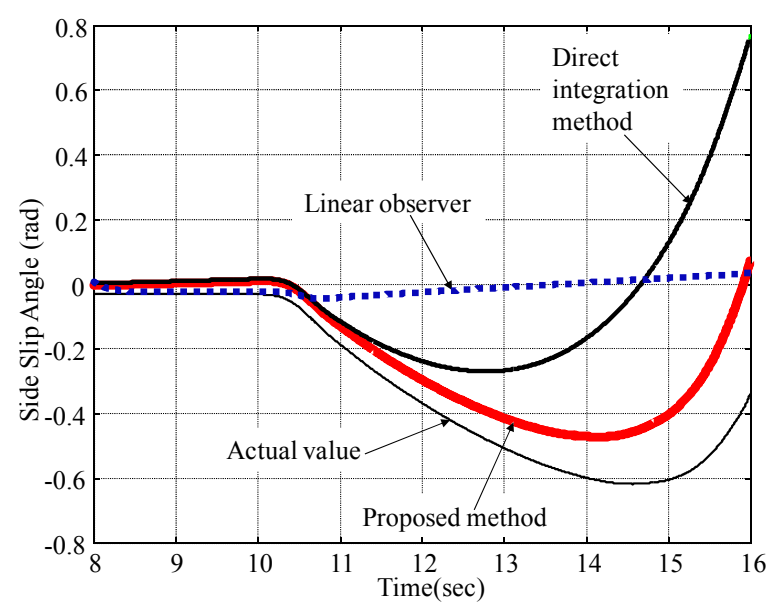

Fig.9 $\beta$ estimation during braking in turn

\section{6. センサオフセット対策}

式(17)の一部をブロック図に表わすと図 10 になる. 式(1)で表される直接積分法は図 10 のハッチング部分に 相当する．直接積分法ではセンサオフセットが積分されて，推定值のドリフトにつながることがわかる.

一方, 提案する推定器では式(11)に基づいて構成され, 横方向運動だけでなく前後方向運動も考慮した才 ブザーバ構成となっている. 予測した前後車速と車速センサ信号との偏差が $k_{1}, k_{2}$ でフィードバックされる ため，純粋な積分器がなくなり，センサオフセットに起因するドリフトを抑制する.

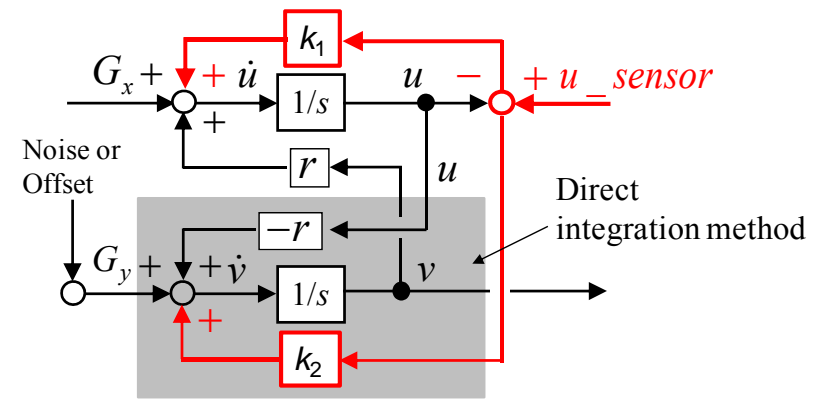

Fig.10 Block diagram of Estimator

図 11 に, 横加速度センサに $0.05 \mathrm{G}$ のオフセットがあるときのシミュレーション結果を示す. 車速 $100 \mathrm{~km} / \mathrm{h}$ で 2 回車線変更を行ったときの車体スリップ角を推定した. 但し, 前後方向の重力加速度成分の影響は除去 して計算した.

直接積分法 (実線) ではオフセットの影響を直接受けて，推定值がドリフトしている，一方，図 10 の方法によ る推定值を(1)Extended Kalman Filter w/o hysteresis として, 図 11 中に太線で表示した. 車線変更の間は真值に近い 推定をするが，直進時には直接積分法と同様にドリフトすることがわかる.

直進時にはヨーレイト $r$ がゼロになり $u$ と $v$ の干渉が除去されるため, 図 10 のカルマンゲインによるフィード バック効果がなくなる．その結果，純粋な積分器を使って推定する構造となる．つまり，ヨーレイトがゼロの間 は直接積分法と同じ構成になる. 


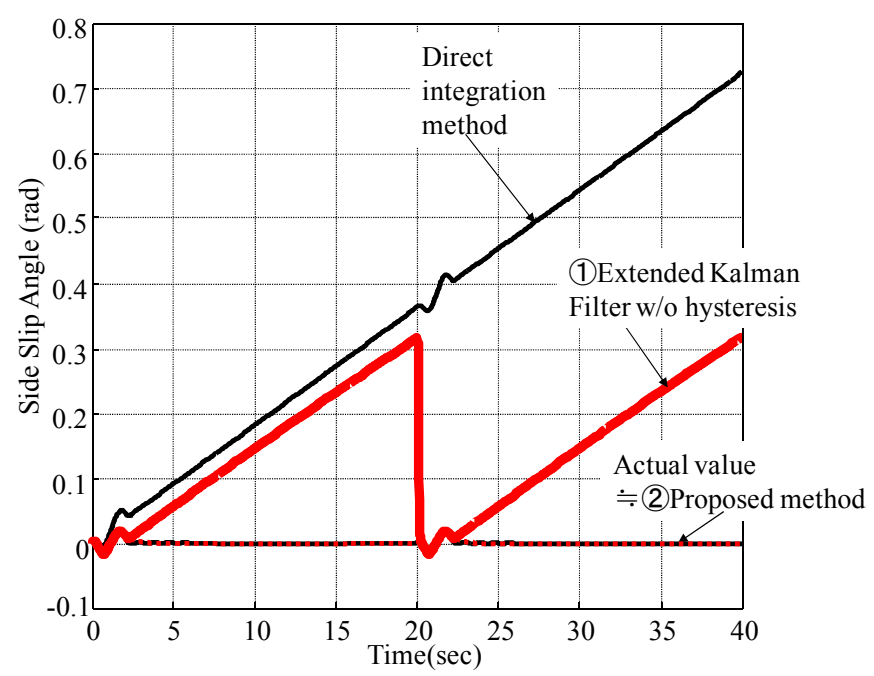

Fig.11 The influence of the sensor signal offset to the estimation

そこで図 12 に示すように, 推定器の中の演算ではヨーレイトの絶対值が設定值以下にならない構成とした. ヒ ステリシスは，直進付近で演算に用いるヨーレイトのハンチングを防止するために設けている.

図 12 の方法を用いると, ヨーレイトが小さい範囲では推定誤差が若干大きくなるものの, 推定值のドリフトは 抑制できる. 図 12 のマップを使った場合の推定結果を, 図 11 の(2)Proposed methodに示す.ヒステリシス幅を大 きくすると，ヨーレイトが小さい領域での推定誤差は大きくなるが，推定值のドリフト抑制効果も大きくなる.

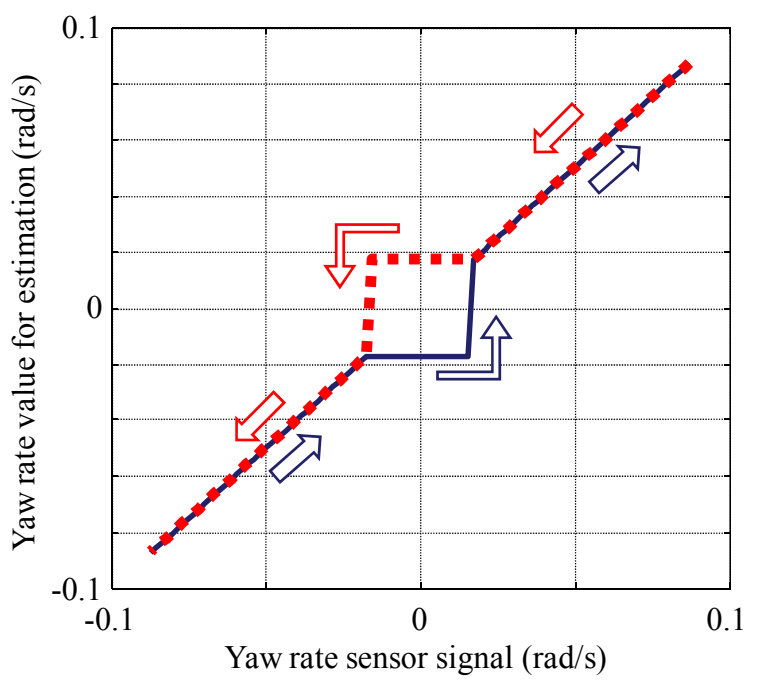

Fig.12 Yaw rate value for estimation

以下, センサ信号にオフセットがある場合の推定結果を示寸. 条件は 5 章で記した路面 $\mu=0.4$ でのダブルレー ンチェンジとする，表 1 に示すように，印加するオフセットと想定する共分散の組み合わせについて 4 仕様を準 備した.

Table 1 The Specification of calculation concerning about sensor offset and covariance supposed

\begin{tabular}{|c|c|c|}
\hline & Covariance A & Covariance B \\
\hline Add longitudinal acceleration offset & (1) & (2) \\
\hline Add Lateral acceleration offset & (3) & (4) \\
\hline
\end{tabular}


式(12)の状態遷移方程式において外乱 $w_{1}, w_{2}$ を駆動するノイズの共分散值を 1 とした. 表 1 の共分散 $\mathrm{A}$ は前後 運動の外乱を多く見積もり, 前後速度と横速度のプロセスノイズの分散值をそれぞれ 100 と 0.01 に想定している. 一方共分散 B では横運動の外乱が多いことを想定して, 前後速度と横速度のプロセスノイズをそれぞれ 0.01 と 100 に設定した. 表 1 に示寸(1)〜(4)の 4 仕様の推定結果を図 13〜16 に示寸.

図 13,14 には計算仕様(1), (2)の結果を示す.いずれも前後加速度センサに $0.01 \mathrm{G}$ のオフセットを加えた状態で のダブルレーンチェンジ時の推定值を評価している. 図 13 の仕様(1)では前後方向の外乱を大きく見積もり, 真值 に近い推定值が得られた. 前後速度を推定する際に, 式(12)の状態遷移方程式に基づいた予測值よりも, センサ 計測值を大きく反映した結果と言える. 図 10 のフィードバック係数で言うと, $k_{1}$ が相対的に大きくなり前後加速 度の外乱を抑制する.

図 14 には前後方向の外乱を小さく見積もった仕様(2)の結果を示す.この場合は，図 10 の $k_{1}$ が相対的に小さく なり，前後方向外乱の影響で推定值に誤差が生じる.

横加速度にオフセット $0.01 \mathrm{G}$ のオフセットを加えたときの推定值を図 15,16 に示寸. 図 15 の仕様(3)では, 前後 方向の外乱を大きく見積もり, 相対的に横方向外乱の共分散を小さく設定した. その結果図 10 のフィードバック 係数 $k_{2}$ が小さくなり, 横方向外乱の影響を受けや寸くなっている. 真值に対する推定誤差も大きく発生した.

一方，図 16 の仕様(4)では横方向外乱の共分散を大きく設定したため，図 10 の係数 $k_{2}$ は大きな值となる. この フィードバックが横方向外乱の影響を抑圧し，誤差の小さな推定值が得られた。

また全ての仕様において, 図 12 に示すヨーレイトマップの効果で推定值のドリフトが抑制された. ただし上述 のように，共分散の設定の仕方によって推定精度が左右される課題が見られた．本課題については，現状では明 確な対策方法は得られていない.

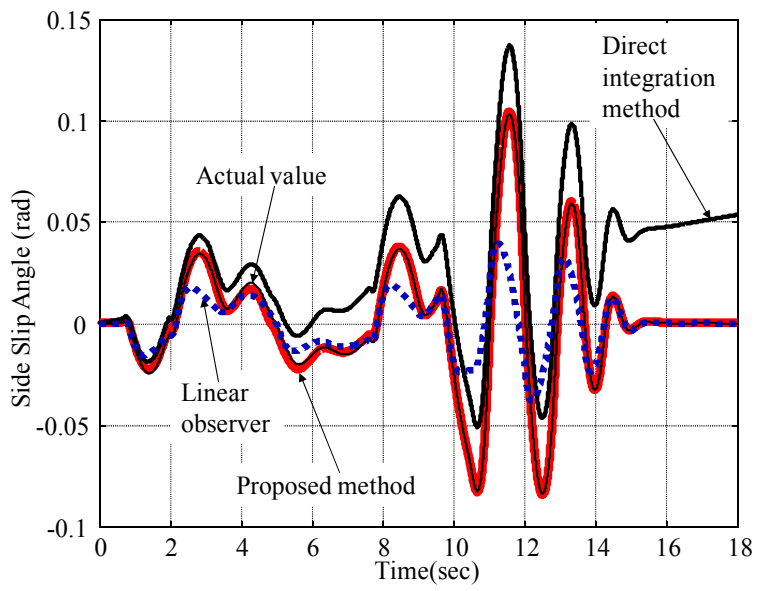

Fig.13 $\beta$ estimation condition (1)

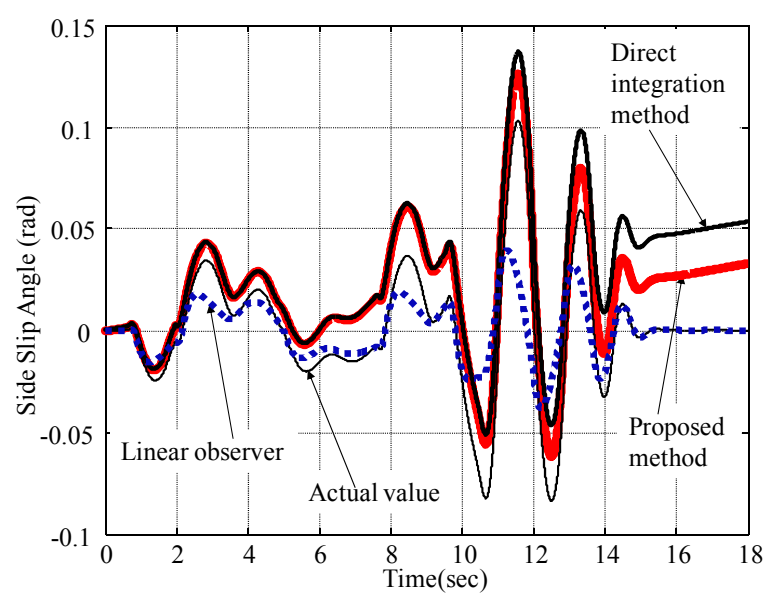

Fig.15 $\beta$ estimation condition (3)

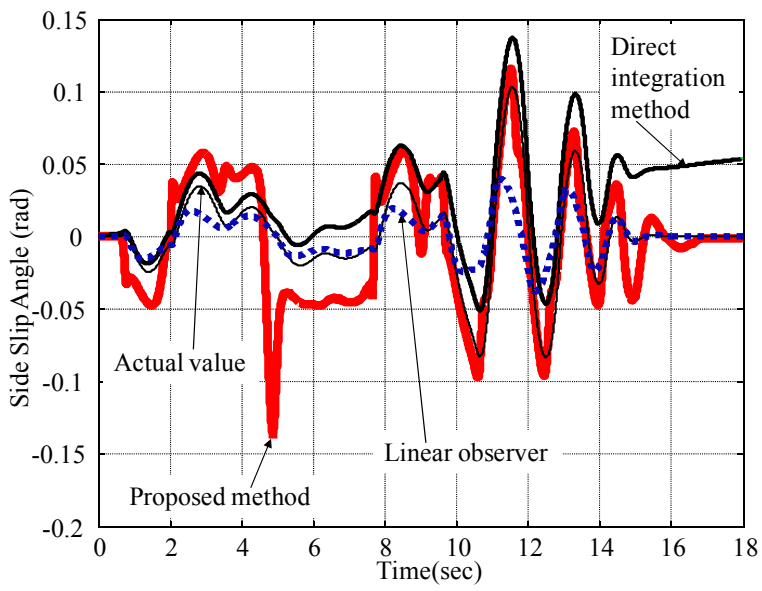

Fig.14 $\beta$ estimation condition (2)

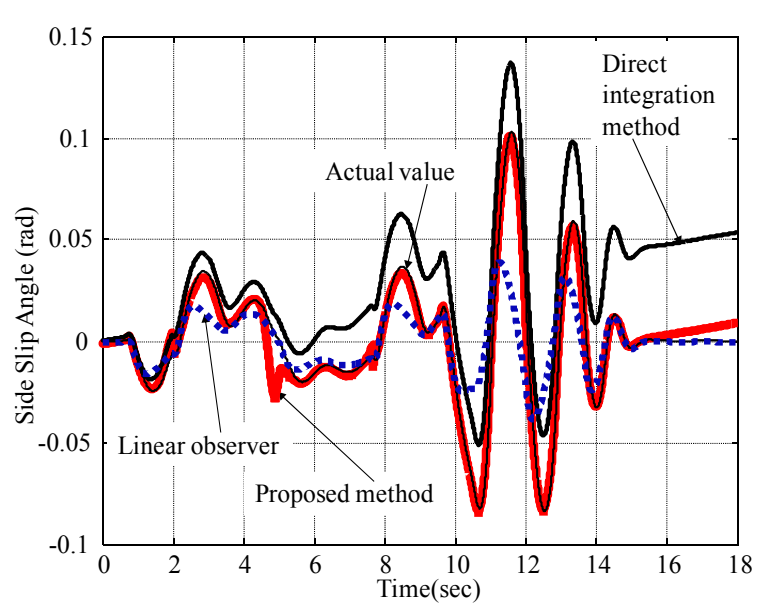

Fig.16 $\beta$ estimation condition (4) 


\section{7. 結}

1. 前後方向運動も考慮して, 直接積分法を元にオブザーバを構成した. さらに重力加速度の影響などを外乱 とした拡大系について拡張カルマンフィルタを構成した.

2. 演算に用いるヨーレイトをゼロにしない計算用マップを用いることで，センサオフセットに対するドリフ 卜抑制効果が確認された.

3. 提案手法の効果を CarSim を用いて机上計算にて確認したところ, 従来の推定手法に比べて推定誤差の抑 制効果が見られた。

4. 実用化に向けては, 拡張カルマンフィルタ設計におけるノイズの共分散設定方法に関する課題が確認され た.

\section{謝 辞}

本稿の作成に際して，(株)豊田中央研究所の小野英一氏には大変貴重な論文，ご助言を頂きました．感謝の意 を表します．また本研究はJSPS 科研費 24560258 の助成を受けたものです。心よりお礼申し上げます.

\section{文献}

(1) 山内雄哉, 藤本博志, “電気自動車におけるヨーモーメントオブザーバとラテラルフォースオブザーバを用いた車 両姿勢制御法”，電気学会論文誌，Vol.130, No.8 (2010), pp.939-944.

(2) 高橋直樹，藤本博志，“コーナーリングスティフネスと車両横すべり角の推定に基づく電気自動車のヨーレート制 御法に関する一考察”，電気学会研究会資料. IIC-06-04 (2006), pp.17-22.

（3）青木良文, 堀洋一, “電気自動車における車体すべり角オブザーバのロバスト化と実車データによる検証”, 電気 学会論文誌. D, 産業応用部門誌. Vol.125, No.5 (2005), pp.467-472.

(4) 大多和恭行, 藤本博志, “電気自動車におけるタイヤ横力センサとアクティブ操舵を用いた横すべり角の推定と制 御”, 電気学会研究会資料. IIC-10-103 (2010), pp.35-40.

（5）小野英一，三浦有美子，安富大祐，山口克之，“3 軸加速度・2 軸加速度センサを利用した姿勢角推定”, 自動車技 術会論文集, Vol.41,No,1(2010), pp.7-12.

(6) 塩澤裕樹, 横手正継, 縄野昌明, 毛利宏, “車体横滑り角推定手法の開発”, 日本機械学会年次大会講演論文集, Vol.2006, No.7 (2006), pp.95-96.

（7）永井惊也，塩澤裕樹，孕石泰丈，毛利宏，“拡張カルマンフィルタを用いた車体スリップ角の推定”, 日本機械学会 第 21 回交通・物流部門大会講演論文集(2012), pp.89-90.

（8）山口裕之, 浅野勝宏, 天野也寸志, 十津憲司, 西尾彰高, “車体横すべり角推定法の開発”, 日本機械学会論文集 C 編, Vol.67, No.659 (2001), pp.2291-2298.

（9）松井俊樹，菅沼直樹，藤原直史，“ステレオビジョンを用いた車両横すべり角の計測”，日本機械学会論文集 C 編， Vol.71, No.711 (2005), pp. 3202- 3207.

（10）天野也寸志，“車両運動制御にかかわる推定技術”，システム制御情報学会誌，Vol.42, No.11 (1998), pp.623-630.

(11) 加藤学, 磯田桂司, 湯浅寛夫, “ニューラルネットワークを用いた車体重心スリップ角の推定”, 自動車技術会論文 集, Vol.26, No.1 (1995), pp.57-62.

(12) 山口星一郎, 前田貴信, 横井博一, “ボルテラニューロンネットワークを用いた車両の横滑り予測システム”, 電 子情報通信学会技術研究報告. NC, ニューロコンピューティング, Vol.105, No.419 (2005), pp.89-92.

（13）佐々木秀明, 西牧貴俊, 井上幸夫, “高機動装輪車両の研究-ニニーラルネットワークを用いた横すべり角の推定”, 防衛庁技術研究本部技報, Vol.6688 (1999), pp.1-25.

(14) 入江南海雄，“緊急回避時における人間-自動車系の挙動について”，日産技報，Vol.12 (1977), pp.3-14.

(15) 森正樹, 菅沢深, “車体横滑り角が操舵に及ぼす影響”, 日本機械学会年次大会講演論文集, No.7 (2010), pp.423-424.

(16) 安部正人, 自動車の運動と制御 (2008), pp.11-70, 東京電機大学出版局.

(17) 原田宏, 自動車技術者のためのビークルダイナミクス (2005), pp.6-11, 産業科学シズテムズ. 
(18) 谷萩隆嗣, カルマンフィルタと適応信号処理 (2005), pp.1-47, コロナ社.

(19) Sebastian Thrun, Wolfram Burgard, Dieter Fox, 上田隆一, 確率ロボティクス (2007), pp.3-77, 毎日コミュニケーショ ンズ.

(20) ギルバートストラング，山口昌哉，井上昭，線形代数とその応用 (1978), pp.15-33，産業図書.

(21) 西山清，最適フィルタリング (2005), pp.56-62，培風館.

(22) 飯國洋二，適応信号処理アルゴリズム (2000), pp.23-42，培風館.

(23) 谷萩隆嗣, デジタル信号処理の理論 1-基礎・システム・制御 (1985), pp.46-55, コロナ社.

(24) CarSim : Mechanical Simulation Corporation. 